\title{
Regional disparity in modern First Nations' treaty-making
}

\author{
Anthony Gatensby
}

\author{
This study was conducted under the supervision of Professor Carol Dauda, \\ Department of Political Science, College of Social and Applied Human Sciences \\ University of Guelph, Guelph, Ontario, Canada
}

\begin{abstract}
First Nations' self-government treaties have arisen solely in British Columbia, to the exclusion of every other Canadian province. At first glance, the amount of historical treaties enacted in what is now Ontario prevents new claims from being pursued. Therefore, the assumption exists that because the majority of British Columbia's land mass was never formally ceded to the Crown, the opportunity to do so has now presented itself. However, identifying the amount of historical treaties as the sole influence over the contemporary process of land claims is an assumption that excludes the importance of regional circumstances in emerging self-government treaties. Therefore, the intention of this paper is to establish that this assumption is inadequate, and that regionalism better explains the historical, political, legal, and geographical reasons why First Nations' self-government has surfaced exclusively in BC.
\end{abstract}

A ccording to Christopher Alcantara, professor of Political Science at Wilfrid Laurier University, the academic consensus about what the causes of the changes in Aboriginal policy is still remarkably underdeveloped [1]. The development of First Nations' (henceforth referred to as Nations) self-government after a century of assimilationist policies such as the Indian Act (1876) and the White Paper (1969) demonstrates one such change. Yet, the explanation as to why this change would occur, and furthermore, why self-government treaties have been regionally restricted to the province of British Columbia remains unanswered. One possible answer rests on the heavy cession of land to the Crown in central Canada, and the complete lack in BC, which creates the contemporary opportunity to complete the 'unfinished business' of land claims in western Canada (Figure 1) [2]. However, this assumption only identifies one piece of a comprehensive puzzle, which includes the Aboriginal exposure to colonial ideology, Aboriginal-settler interconnectivity, intraconnectivity within Nations, and mobilization tactics, above and beyond the amount of ceded and unceded territory (Figure 2). The characteristics help identify the divide, as much geographical as political, that can be drawn between $\mathrm{BC}$ and the rest of provincial Canada in regards to the isolation of self-government treaties.

\section{EXPOSURE TO COLONIAL IDEOLOGY}

To begin to understand the contemporary process, it is first necessary to understand the historical contributions to it. There have been different ideologies employed by settler governments in their approach to relationships with Aboriginal Nations. The existence of ideology can be found in an analysis of both formal and informal colonial policy, which reflect overall settler attitudes. The differing levels of exposure to these ideologies, and the shifting between them, is a factor which contributes to the formation of a contemporary process of land claims, most directly impacting interconnectivity and intraconnectivity of Nations.

\section{The Valois-Angoulême Period}

The first, that which I name the "Valois-Angoulême period' after France's monarch at the time of the New France settlement, existed from 1534-1837. It marked a period of remarkable peace and mutual respect of cultures between French colonials and Aboriginal inhabitants. John Ralston Saul, in his book A Fair Country, remarks on the huge absorption rate of Europeans into Aboriginal communities, reasoning that intermarriage played a huge role in breeding a relationship of amity. Specifically, Saul remarked on the hierarchy by which colonists achieved great mobility and that by "marrying into the indigenous world, most of the newcomers were marrying up. They were improving their situations socially, politically, and economically" [3]. Although the motivation there exist strong overtones of the economic and political advantage for settlers personally, Saul states that it was a matter of policy throughout the colonies to create cultural métissage [4]. In one instance, Saul makes a reference to a quote by the French explorer and founder of Quebec City Samuel Champlain: "our young men will marry your daughters and we shall be one people" [5]. Saul recognizes the rarity of what is being said when he remarks that he "can't think of a European governor - French, British or other - making such a policy statement in any other colony from the sixteenth to the nineteenth century" [6]. Thus, the resulting Métis offspring would have been looked 
Amount of Ceded Territory

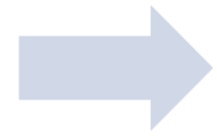

Contemporary Process of Land Claims

Figure 1. The assumption that the amount of ceded territory determines the contemporary process of land claim

upon as a success in terms of alliance and a further route to stabilizing the fur trade. It comes as no surprise that Saul chose to quote Champlain in explaining the amity between the French and the Aboriginals, because Champlain's ideology was concretely reflected in his policy of mutual acculturation. For instance, he encouraged young Frenchmen to explore the unknown parts of the New World, in an effort for them to learn indigenous languages and cultural rites [7]. These alliances, often with the Ojibwa Nation, were heavily integrated into the social workings of colonial life. This was so much so that the phenomenon of a French trader marrying an Aboriginal woman was an established expectation, as Ojibwa expert Peter Schmalz comments, in order to invest and establish interest in the various Aboriginal communities [8]. This time period of cooperation and friendship, a relationship much less colonial and more of equals, never existed in British Columbia.

Various scholars have noted the startlingly weak penetration of Europeans in pacific Canada, noting that what little penetration that did exist, mostly in the form of temporary outposts, was of little significance to the subsequent history of the area [9]. This included the limited westward expansion via the colonial presence east of the Rocky Mountains, and via the Pacific Ocean as well. Essentially the 'Indians', as they were called, escaped undue interference during early periods of exploration simply because no "European power considered the Pacific Northwest sufficiently important to make the effort necessary to secure exclusive sovereignty. The more important goal was to ensure that no other nation did so" [10]. Aboriginals were able to freely establish lucrative fur-trading posts, and adapt quickly to the presence of imperial powers in light of their indifference. Even prior to the first colonial creations, European traders chose to preclude violence, as their "preferred tactic in the face of Native provocation was to anchor a ship just off a Native village and prepare its guns for action, a display intended to produce terror and compliance without killings" [11]. Thus, the specific regionalism of the Aboriginal nations in this territory was characterized largely by an independence from intervention during the years of amity fostered between the French and Ojibwa in the east. Statistics of the population during various years in British control reveal how slow European penetration was until almost the $20^{\text {th }}$ century.

The first colonial creations in the region were of both Fort Victoria (1846) and the Colony of Vancouver Island in (1849), which is substantial considering the territory was
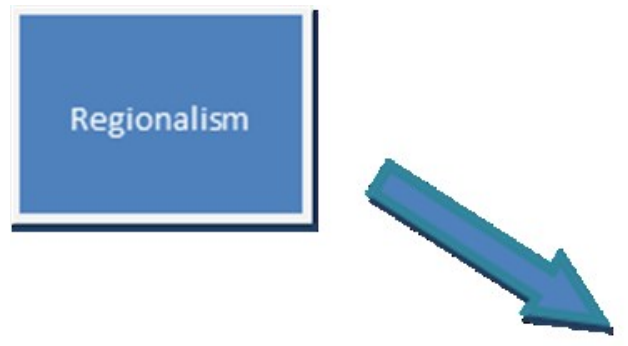

Amont of Ceded Tenitary
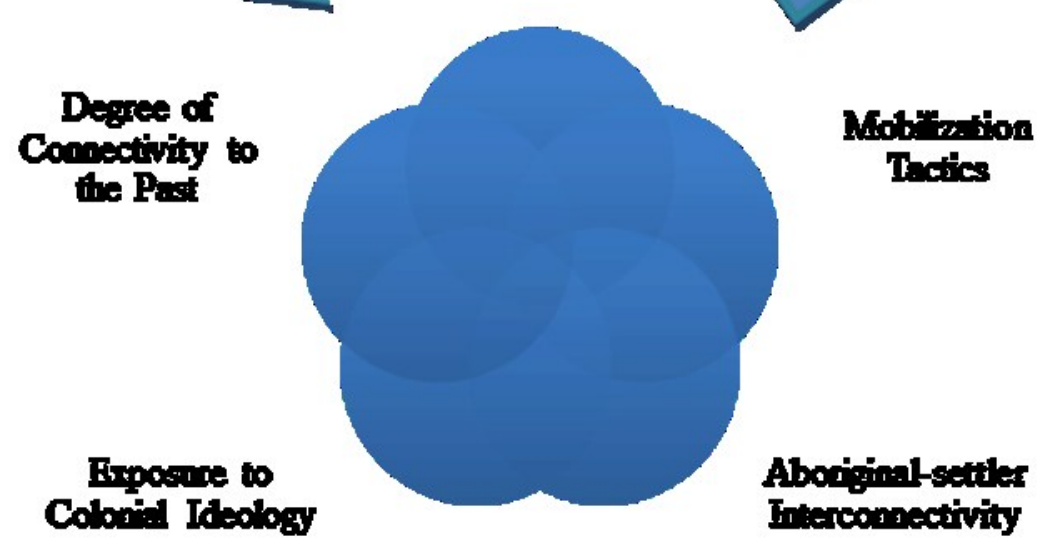

Contemporary

Process of Land

Claims

Figure 2. The regional characteristics that have influenced the contemporary process of land claims 
considered British as early as 1790. Their further amalgamation into the colony of British Columbia did not occur until 1866, and it was several decades until white settlers predominated (see Table 1). Paul Tennant, professor emeritus at the University of British Columbia, comments on this phenomenon by describing how "Whites began to arrive in significant numbers only in the $1850 \mathrm{~s}$, and not until the 1890 s did effective white control extend to the last of the major Native groups" [12].

\section{Victorianism}

Victorianism was a form of imperialistic renewal that took place in the settler colony in the mid $19^{\text {th }}$ century; it was characterized by a resurgence of European ideals of supremacy, subjugation, and power. Victorianism came, most undeniably and concretely in the form of new Crown policy. In 1847, a British governmental commission produced the Report on the Affairs of the Indians in Canada, creating the first incarnation of assimilation policy in the colonies [13]. This policy had two intended effects that aimed to violate the equality between Europeans and Aboriginals established during the era of Valois-Angoulême: first, encroachment onto Aboriginal land by Europeans would be rewarded, and second, there would be no restriction on over-fishing/over-hunting by Europeans on Aboriginals land [14]. The idea of Victorianism, the idealization of imperial subjugation, was easily found in this and subsequent policy. The purpose was to assimilate the Aboriginals into 'superior' European lifestyles, which included drastic attempts at religious conversion. This ideology led to several colonial enfranchisement policies, such as the Gradual Civilization Act 1857 in Upper Canada, which outlined methods for Aboriginals to acquire British citizenship in exchange for any previous Aboriginal identity [15]. Much more devastatingly, the Act for the Gradual Enfranchisement of Indians 1869 and the Indian Act 1876 institutionalized these policies at the federal level. When British Columbia joined Confederation in 1871, western Aboriginals became subject to the federal policies already in place.

The root of Victorianism as an ideology can be found by tracing the roots of the United Empire Loyalists, a group of 46,000 American refugees who settled in Upper and Lower Canada (approx. 10,000), New Brunswick (approx. 16,000) and Nova Scotia (approx. 20,000) after the British defeat in the American Revolutionary War [16]. These Loyalists, as their name implies, were characterized primarily by their undying loyalty to the British Empire, to its unity and to its preservation. The initial tension between the Loyalists and local Aboriginal were mostly based on superficial rumours, such as speculation by the new settlers on whether the best land was already procured and granted to the Aboriginals. However, this tension has been attributed to resettlement pains, along with typical unrest and unease [17]. The more damaging and long-lasting effects did not emerge until the 1850s, with Confederation becoming a more tangible reality with each passing year. A new assortment of pressures, including the question of national origins, the overwhelming nationalist American histories, and the placement of prominent Loyalist descendants in powerful governmental positions, contributed to the establishment of a new identity based on a new ideology [18]. The culture of the majority and the majority's needs were bringing into question the fundamental role of Aboriginal involvement. Norman James Knowles, in his book Inventing the Loyalists explains how history was forcefully manipulated to serve a certain collection of goals. While not specifically concerned with the repercussions for Aboriginals, he comments that there was an [19]

emergence of a new historical consciousness in the 1850s. This development was largely a product of nationalist sentiment and expansionist ambitions that accompanied the process of state formation and the province's economic growth. The past was invoked and recalled by provincial leaders interested in the creation of an official history that could be used to promote unity, build a national identity, and uphold social and political order.

This revitalized legacy of imperialistic renewal was one factor which influenced Aboriginal policy. The sentiment was never more powerful than in 1867 , with the creation of the new Confederation and the desire to institute 'peace, order and good government', lasting until the White Paper incident in 1969 with the implementation of, and reorientation to, modern treaty negotiations.

\section{SHIFTING IDEOLOGY \& CONNECTIVITY}

The shift between ideologies created a destabilization of the Aboriginal consciousness. Not only did this skewed balance of power serve to undermine the relationship between eastern Aboriginals and the colonial state, but it established the relationship between Aboriginals and nonAboriginals as one of the 'mainstream' or the normal, versus the 'other' or the abnormal, which is to be either normalized or excluded [20]. This was especially devastating for the Métis; although they were always identified as 'half-breeds', they were now denied affiliation to both their Aboriginal and European roots. H.Y. Hind, in an expedition in the 1850 s to assess the agricultural capability of prairie land, reported that although the Métis may charade as Europeans, they have no claim to land in the Red River Colony in what is now Manitoba [21]. For those Métis and Nations outside of BC, Aboriginals were defined by their pre-contact qualities while ignoring any evolution of these qualities was dismissed. In this regard, it is not surprising that Aboriginals were clinging to the values introduced by the Valois-Angoulême period. As Victorianism grew, Aboriginals were faced with a colonial power in Ottawa that was violating, outright deliberately and systematically, the promises in treaties with the intent to force Aboriginals into federally imposed settlement plans [22]. This confusion of identity affected the ability of 
Aboriginals to mobilize politically against the colonial state as their identity had grown to encompass Europeans. Paul Tennant generalizes the political condition of eastern Aboriginals by noting that globally in [23]

the English-speaking new world countries ... the indigenous groups were nowhere a political threat once the new regimes were established. In Canada east of the Rocky Mountains, there were instances of protest and lobbying, but no lasting political organizations.

Instead of these institutionalized channels, the Aboriginals of eastern Canada often chose strategies of direct confrontation rather than strategies based on the values such as the supremacy of law. This demonstrates an ideological rejection of 'official' channels that had been formalized by the 'illegitimate' state. I argue that when a previously valued culture is undermined and subjugated by a change in the majority's ideology, a sense of betrayal, confusion, and disorder amongst the newly disadvantaged would manifest these volatile emotions in violence rather than in political activism and organization. Tennant, for example, acknowledges the implication of regionalism and its effect on political organization beginning in the 1900s. In his article, Native Indian Political Organization in British Columbia, he states that in [24]

British Columbia political adaptation was the predominant response attempted by Indian leaders once the immigrant regime had become firmly established ... Organized violence against newcomers was infrequent and isolated; revitalization movements were localized and temporary; social breakdown and personal demoralization, while certainly in evidence, were not sufficient to impede the emergence of leadership or the functioning of organizations; and, as the presence of political adaptation implies, there was an absence of the passivity, fatalism and lethargy evident among indigenous groups elsewhere.

The correlation can thus be shown to exist between the nature of the specific regional context, defined primarily by the consequence of shifting between ideologies and the action of the government prior to and after 1836, and the differential actions between Aboriginals in British Columbia and those east of them. The historical amount of cultural interconnectivity, or lack thereof, has also supported this correlation.
Table 1. Population and racial diversity of British Columbia from 1870 to 1941

\begin{tabular}{ccccc}
\hline Year & \% White & \% Asian & \% Indian & $\begin{array}{c}\text { Total } \\
\text { Population }\end{array}$ \\
\hline 1870 & 24.9 & 4.3 & 70.8 & 36,247 \\
\hline 1881 & 39.3 & 8.8 & 51.9 & 49,459 \\
\hline 1891 & 55.1 & 9.1 & 35.9 & 98,173 \\
\hline 1901 & 74.8 & 10.9 & 14.3 & 178,657 \\
\hline 1911 & 87.1 & 7.8 & 5.1 & 392,480 \\
\hline 1921 & 88.2 & 7.5 & 4.3 & 524,582 \\
\hline 1931 & 89.1 & 7.3 & 3.5 & 694,236 \\
\hline 1941 & 91.8 & 5.2 & 3.0 & 817,861 \\
\hline
\end{tabular}

Source: "Class and Race in the Social Structure of British Columbia, 18701939." British Columbia Studies (1980): page 28.

\section{Interconnectivity}

The word 'interconnectivity' implies a degree of interaction between two cultures. As the interconnectivity between the Aboriginals and settlers grew, Aboriginal culture in Central Canada underwent significant changes, specifically as their society absorbed European goods and technology. Schmalz, an Aboriginal expert who has written extensively on the Ojibwa of southern Ontario, declared the Ojibwa to be one of the main Aboriginal trading groups that benefitted from the commercial rivalry between the British and the French in the early 1700s. With the warring colonial powers of England and France pitted against one another, it is recognized that their [25]

conflict created a system of native alliances that attempted to gain hegemony in the beaver-skin trade. Those Indian traders who would not conform to the wishes of the dominant aboriginal groups faced pillage, dispersal, or extermination. At the same time, those groups which did exchange furs for the coveted European goods greatly increased their material standard of living and their power.

The advent of the fur trade was clearly changing the social and political goals of the Aboriginals in Upper Canada. As a consequence, it is logical that their way of life grew to depend on such goods such as muskets, metal knives, hatchets and kettles as integral to everyday life, essentially displacing traditions and cultural practices. The adaptation was likely a logical strategy to the Aboriginals, because often these tools and materials were much more efficient and sturdy than the ones fashioned on their own. Schmalz echoes this sentiment by remarking that during "the first half of the eighteenth century a growing number of Ojibwa began to look upon European trade goods as a necessity rather than a luxury" [26]. This dependency was even more pronounced because of the consistent exposure to new goods and technology over time, resulted in the erosion of traditions as adaptation changed the social structure of their bands. 
A good example of this was observed in 1718 at Madeline Island, an isolated island in Lake Superior where there had been a 20-year hiatus from trading. The Captain who landed there discovered dying Aboriginals, starving because the traditional skill of making stone, bone, and wood tools had been lost [27]. The erosion of tradition, the same erosion found at Madeline Island, was arguably not because the Aboriginals were passive, barbaric, and easily manipulated. More likely it is because they trusted the colonials who were, in the spirit of the Valois-Angoulême period, showing them good faith. A high degree of interconnectivity, which conceptually phrases the relationship between Aboriginal culture and European culture in the language of power struggles, demonstrates how many tribes suffered as a result of their growing dependency on Europeanism. After New France fell in 1763, it appeared as if this period of recognition and cooperation would continue when the British Crown implemented the Royal Proclamation (1763), appealing to the Aboriginals, if only superficially. However, the current grievances being resolved today would point to that intention not being fulfilled over the last 200 years.

\section{Intraconnectivity}

Where the term 'interconnectivity' implies a connection between cultures, the term 'intraconnectivity' implies a connection within one's culture. The disruption of Aboriginal communities, through instances such as the residential school system and through land relocation measures, placed at risk this intraconnectivity. Since oral history is the predominant method of generationally extending culture, the intraconnectivity in Aboriginal Nations was susceptible to major disruption. While Nations in the east were drawn into European wars and bartered with land consistently, the same is not true of Nations in the west. Rather, the intraconnectivity of the Aboriginals in the west was left exceptionally strong because there was "no armed conquest, no mass displacing of villages and relatively little forced admixing of differing communities. The Native past was not cut off' [28]. The tactic of intermarriage as an attempt to stabilize the fur trade in the east, and for the settlers' personal advantages was extremely uncommon in the west when the settling communities began to expand heavily in 1870s [29]. As well, because land was not ceded to the Crown, Nations in the west did not identify and relocate to reserve territory the way it had taken place in the east. While the Nisga'a land commission of 1890 shows Nation-cohesiveness in itself, it does not fully convey the extent of western intraconnectivity. Twenty years later, while then Prime Minister Wilfrid Laurier was campaigning in Kamloops for his re-election, he was presented with a letter that was co-written by the Chiefs of the Shuswap, the Okanagan and the Couteau Tribes, on August $25^{\text {th }} 1910$. The letter established the existence and the nature of their growing political strength.. The letter included a powerful clause that stated [30]:

\begin{abstract}
So long as what we consider justice is withheld from us, so long will dissatisfaction and unrest exist among us and we will continue to struggle to better ourselves. For the accomplishment of this end we and other Indian tribes of this country are now uniting and we ask the help of yourself and government in this fight for our rights.
\end{abstract}

With the establishment of various Indian Rights Associations around this time and the continued perseverance of the Nisga'a land claim, the strength within western Aboriginal intraconnectivity, in its uniqueness, was growing in prominence. This, coupled with the relative weakness of their interconnectivity with Europeans, created a regional circumstance which allowed them to pursue a form of agency which utilized mobilization to pursue policy change.

\section{Mobilization TACTICS}

Empirical evidence suggests that sustained political mobilization is one of the core facets of rights-based legislation. Identifying the conditions for this kind of mobilization has been the work of Charles Epp, and led to the development of what he has aptly named the 'supportstructure explanation'. In his book The Rights Revolution, Epp proposes the idea that the ability for human rights to grow into law is connected directly from cohesive grassroots pressure and a sustained, fundamental access to resources [31]. This theoretical model lends itself to the Aboriginal experience ever since first contact with Europeans, and furthermore, it helps to explain the development of Aboriginal rights, including their right to self-government and land.

The support-structure explanation claims that civil rights, those outside of the business-oriented commercial sphere, is not an individual effort. Rather, Epp explains, it "grew out of the collective efforts of a large number of people who relied on organizational, legal, and financial resources that had been created by broad, collective efforts" [32]. This mobilization relies on the premise that the pursuance of lawsuits, and their ability to be successful in that pursuit, is not strictly attached to the opportunities provided by a constitution, by judicial decisions or from the expectations that have arisen from popular culture [33]. Epp claims that this flows logically from two points. The first claim is that the recognition of rights in law requires litigation that has been widespread, and sustained; it must have longevity and spatial capacity. Many supreme courts are selective in the issues that they preside over, and often the issue presented by the case must have exerted considerable pressure on the judicial system. For this to occur, widespread and sustained litigation has appellants deal with the judiciary, a process that is notably, as Epp puts it, "time-consuming, expensive, and arcane; ordinary individuals typically do not have the time, money, or expertise necessary to support" these kind of resource- 
intensive lawsuits" [34]. This makes extensive resources fundamental in promoting long-term change through the judiciary, which by nature promotes small incremental changes, making it difficult to achieve major change without consistent pressure. This can only be achieved when there are various sources to sustain the pressure, including organizations which collectively pursue rights, legal expertise that is both competent and creative, financial resources, and at times even governmental rightsenforcement agencies or watchdogs. Access to this supportstructure was fundamental to the ability to pursue court cases and influence a favourable change in policy direction. The support-structure becomes a practical necessity as the government's attempts to quash land claims became more resolute.

In the late $1920 \mathrm{~s}$, three decades after the establishment of the Nisga'a land claim, Ottawa was noticeably losing patience with their policy of allowing debate with, and petitions from, the Aboriginals. As repeated attempts at reconciliation failed, this frustration became Ottawa's policy; legal 'blockades' were formed with the intent to disperse the intraconnectivity of various Nations. These legislative blockades were at times incredibly pointed: they included a ban on fundraising for Aboriginal claims in 1927; a ban on court cases regarding Aboriginal land in the same year; and the requirement of provincial consent, a rarely granted permission, before anyone was legally permitted to sue the Crown [35]. Their communal support, their associations, and most of all their resolve, allowed the Nisga'a to overcome the ensuing legislative blockades, sustaining their mobilization underneath the legal silences, and continuing to pursue their claims when they were legally permitted to do so decades later. When the era of Victorianism began to deteriorate in the late 1960s, the Nations in British Columbia had created a pressure which could no longer be ignored.

\section{JUDICIAL IMPACT}

The rate at which Nations have mobilized toward the judicial system has varied between British Columbia and the rest of Canada. The result is that the most influential court cases which have allowed Aboriginals to pursue selfgovernment and comprehensive land claims have emerged disproportionately from the west. These Nations have successfully broadened and solidified their rights to land, allowed their tradition to be ingrained and respected in the legal system, and possibly most important, redefined their relationship with the federal government to be one of implied responsibility and fiduciary trust. The consequence of the regional differences has excluded eastern Nations from defining the process by which they establish rights, land claims, and self-governing treaties. These cases, however, did not begin to truly cascade until after the outrage spurred by the White Paper incident in 1969. The policy failure of the White Paper signalled the beginning of a new rightsdiscourse, one characterized by politics of recognition rather than outright assimilation. After 1969, the court cases that affected change were numerous; the rate at which judges were willing to clarify the Constitution in favour of Aboriginals became more rapid than at any point in history since settlement. Aboriginal title was affirmed in $R v$. Calder and clarified in Delgamuukw v. British Columbia in 1973 and 1997 respectively [36]. The Delgamuukw case also resulted in oral tradition being admitted in a greater capacity as a form of legal evidence, providing greater recognition to the Aboriginal way of life. Subsistence rights were given constitutional protection and allowed the courts to define a standard known as the 'Sparrow Test', defined in $R v$. Sparrow, by which subsistence rights can be identified and constitutionally limited [37]. The case also instilled the idea of fiduciary responsibility for the Crown. These cases are among several that have defined fundamental aspects which the land claims process rotates today, all emerging from Nations within BC as a product of the mobilization made possible by broad resource, strong intraconnectivity, and weak interconnectivity with settler governments.

\section{CONCLUSION \& SugGeSTiONS}

As stated previously, the amount of academic literature that explains the causes of the shifts in Aboriginal policy is underdeveloped - yet without this knowledge, explaining why self-governing provisions exist only in British Columbia is a substantial task. This research first attempts to contribute to that body of literature by analyzing what role Aboriginals play in affecting policy direction, and second to use that analysis to dispel the myth that the amount of ceded territory is the sole cause of how the contemporary process has taken shape. In the absence of this myth, the need exists to establish under what conditions Aboriginal groups have been able to encourage governments to alter policy direction. The fact that the evolution of the contemporary process was the result of regional characteristics is a significant one; it suggests that the ability of Aboriginals to alter policy and secure an expanded set of self-governing rights has been indirectly affected by the historical interaction of colonists and Aboriginals. Regionalism points to the effect of colonial ideology, and to what degree the exposure to specific policy initiatives has disconnected Aboriginal groups from their ability to sustain the resources necessary to pursue long-term judicial mobilization. While the amount of land claims provides flexibility in British Columbia for modern treaties to be assessed, it is not the sole, nor most important, reason for the emergence of these treaties.

It is certain that pockets of Aboriginal self-government will continue to develop. Due to the high rate of BC Nations that have committed themselves to the BCTC negotiation process, the anomalies of the Nisga'a and Tsawwassen agreements are sure to be joined by a plethora of new final agreements with self-governing provisions in the coming years. As this research suggests, Aboriginals will continue to be successful in promoting these kinds of agreements to emerge exclusively in British Columbia. Further work is 
needed to establish how these historical impediments to eastern self-government can be overcome, or at the very least weakened. As well, an analysis of the context Yukon, the Northwest Territories, and Nunavut, as well as the analysis of the role of Inuit Nations, may provide valuable insight regarding the impact of regionalism in Canada's north. In the international context, an evaluation of the effect of international rights-legislation, such as the 2007 United Nations Declaration on the Rights of Indigenous Peoples, on Canada's Aboriginal Nations may also suggest a newly opened route to challenge historical barriers. To that effect, it is unclear what role, if any, the legal system will assume in the establishment of Aboriginal self-government east of the Rockies, and into Canada's arctic. As the influence of the west begins to saturate the eastern ideas of mobilization, the question of how this influence will ultimately take shape is still a mystery.

What is clear is that the dissolution of assumptions about the role the colonial, and subsequent Canadian, governments played historically will aid in the clarification of how the contemporary process of land claims has been formed. As a grandiose as it may seem, each resolution brings Canada as a nation today closer to clarifying its own origins and contemporary identity.

\section{ACKNOWLEDGEMENTS}

I would like to acknowledge Dr. Carol Dauda for her support, encouragement, and direction in the creation of this work. It was truly a privilege to work with her, and I am grateful to have had such a dedicated advisor. I would also like to thank the Political Science department at the University of Guelph as a whole, whose insightful professors have broadened and deepened my knowledge of politics in throughout the completion of my BA. I would also like to thank those who supported me in this endeavour, in particular Greggory Johns and his family, who without which, none of this would have been possible.

\section{REFERENCES}

1. Alcantara, C. (2009). Old Wine in New Bottles? Instrumental Policy Learning and the Evolution of the Certainty Provision in Comprehensive Land Claims Agreements. Canadian Public Policy, 35 (3), pp. 324341.

2. INAC. (2009, January 20). Why is Canada negotiating treaties in BC?. Retrieved April 03, 2011, from Indian and Northern Affairs Canada: http://www.aincinac.gc.ca/ai/scr/bc/trts/whengt/index-eng.asp.

3. Saul, J. R. (2009). A Fair Country: Telling Truths about Canada. Toronto: The Penguin Group, p. 9.

4. The term métissage is the French word for miscegenation, and is particularly useful for distinguishing the connection between French colonials and the Ojibwa Aboriginals.

5. Saul, 10.

6. Saul, 10.
7. Surtees, R. J. (1988). Handbook of North American Indians. In W. E. Washburn (Ed.). Washington, D.C.: Smithsonian Institute Press, p. 81.

8. Schmalz, P. S. (1991). The Ojibwa of Southern Ontario. Toronto: University of Toronto Press, pp. 36-37.

9. Barman, J. (1991). The West beyond the West: a history of British Columbia. Toronto: University of Toronto Press, p. 30 .

10. Barman, 30.

11. Harris, C. (1997). The resettlement of British Columbia: essays on colonialism and geographical change. Vancouver: UBC Press, p. 22.

12. Tennant, P. (1990). Aboriginal Peoples and Politics: The Indian Land Question in British Columbia, 1849-1989. Vancouver: University of British Columbia Press, p. 3.

13. Blair, P. J. (2008). Lament for a First Nation: the Williams treaties of Southern Ontario. Vancouver: UBC Press, p. 38.

14. Blair, 39-40.

15. Government of Canada. (2002, October 24). Aboriginal People: History of Discriminatory Laws. Retrieved February 8, 2011, from Government of Canada: Depository Services Program: http://dsppsd.pwgsc.gc.ca/Collection-R/LoPBdP/BP/bp175-e.htm.

16. The total number is debated, but the average estimates are consistently between 40,000 and 50,000. See FremontBarnes, G. (2007). Encyclopedia of the Age of Political Revolutions and New Ideologies, 1760-1815. Westport, Connecticut: Greenwood Press, p. 437.

17. Knowles, N. J. (1997). Inventing the Loyalists: the Ontario Loyalist tradition and the creation of usuable pasts. Toronto: University of Toronto Press, p. 17.

18. Knowles, 27.

19. Knowles, 26-27.

20. Addis, A. (1991-1992). Individualism, Communitarianism, and the Rights of Ethnic Minorities. Notre Dame Law Review, 67, pp. 615-676.

21. Sprague, D. N. (1988). Canada and the Métis, 1869-1885. Waterloo: Wilfrid Laurier University Press, p. 23.

22. Miller, J. R. (1991). Sweet promises: a reader on Indianwhite relations in Canada. Toronto: University of Toronto Press, p. 244.

23. Tennant, P. (1982). Native Indian Political Organization in British Columbia, 1900-1969: A Response to Internal Colonialism. BC Studies, p. 8.

24. Tennant, 8.

25. Schmalz, P. S. (1991). The Ojibwa of Southern Ontario. Toronto: University of Toronto Press, p. 13.

26. Schmalz, 36 .

27. Schamlz, 31.

28. Tennant, 3 .

29. Ward, W. P. (1980). Class and Race in the Social Structure of British Columbia, 1870-1939. British Columbia Studies, p. 31.

30. A copy of this letter was found on a website from a BC Nation. See Williams Lake Indian Band. (2008). Memorial to Sir Wilfrid Laurier, 1910. Retrieved February 9, 2011, from The Williams Lake Indian Band Web site: http://williamslakeband.ca/History/MemorialtoSirWilfred Laurier1910.aspx 
31. Epp, C. R. (1998). The Rights Revolution. Chicago: The University of Chicago Press, p. 2.

32. Epp, 10.

33. Epp, 18.

34. Epp, 18.

35. Foster, H. (1998/1999). Honouring the Queen's Flag: A Legal and Historical Perspective on the Nisga'a Treaty. British Columbia Studies, 120, pp. 24-26.

36. Supreme Court of Canada. (1973, January 31). Calder et al. v. Attorney-General of British Columbia, [1973] S.C.R. 313. Retrieved February 23, 2011, from Canadian Legal Information Institute: http://www.canlii.org/en/ca/scc/doc/1973/1973canlii4/197 3canlii4.html.

37. Supreme Court of Canada. (1997, December 11). Delgamuukw v. British Columbia, [1997] 3 S.C.R. 1010. Retrieved February 23, 2011, from LexUM Web site: http://scc.lexum.umontreal.ca/en/1997/1997scr31010/1997scr3-1010.html.

38. Supreme Court of Canada. (1990, May 31). R. v. Sparrow, [1990] 1 S.C.R. 1075. Retrieved February 23, 2011, from Canadian Legal Information Institute: http://www.canlii.org/en/ca/scc/doc/1990/1990canlii104/1 990canlii104.html.

39. BC Treaty Commission. (2011, February 8). About Us: $B C$ Treaty Commission. Retrieved March 1, 2011, from
BC Treaty Commission Web site: http://www.bctreaty.net/files/about_us.php

40. For a copy of this document in its entirety online, see http://www.ainc-inac.gc.ca/al/ldc/ccl/fagr/nsga/nis/niseng.pdf.

41. A copy of the Tsawwassen Final Agreement can be found online http://www.tsawwassenfirstnation.com/treaty/April\%2009 $\% 20$ -

\%20Tsawwassen\%20First \%20Nation\%20Final\%20Agree ment $\% 20$ English.pdf.

42. Alfred, T. (2001). Deconstructing the British Columbia Treaty Process. Balayi: Culture, Law, Colonialism, 3, p. 57.

43. Corntassel, J. (2008). Toward Sustainable SelfDetermination: Rethinking the Contemporary IndigenousRights Discourse. Alternatives, 33, p. 107.

44. Tully, J. (2000). The Struggles of Indigenous Peoples for and of Freedom. In D. Ivison, \& P. Patton, Political theory and the rights of indigenous peoples (pp. 36-59). Cambridge, UK: Cambridge University Press, p. 42.

45. Milke, M. (2008). Incomplete, Illiberal, and Expensive: A Review of 15 Years of Treaty Negotiations in British Columbia and Proposals for Reform. Vancouver: Fraser Institute, p. 26.

46. BC Treaty Commission. 